\title{
Self Disclosure melalui Media Sosial Instagram (Studi Kasus pada Anggota Galeri Quote)
}

\author{
Asriyani Sagiyanto \\ Akademi Komunikasi Bina Sarana Informatika Jakarta \\ Email: asriyani.ayy@bsi.ac.id \\ Nina Ardiyanti \\ Prodi IImu Komunikasi FISIP Universitas Muhammadiyah Tangerang \\ Email: ardiantynina1@gmail.com
}

\begin{abstract}
ABSTRAK
Penelitian ini bertujuan untuk mengetahui konsep Johari Window anggota Galeri Quote dalam melakukan kegiatan self disclosure melalui media sosial Instagram. Penelitian ini adalah penelitian kualitatif dengan pendekatan studi kasus. Teknik analisis data dilakukan melalui observasi pada akun Instagram Galeri Quote, yaitu dengan cara menganalisis postingan teks berupa komentar-komentar yang diberikan pengguna Instagram. Analisis data dilakukan dengan menggunakan model Miles \& Huberman karena berkaitan dengan masalah penelitian, yaitu self disclosure pada anggota Galeri Quote. Hasil penelitian menunjukkan bahwa anggota Galeri Quote memanfaatkan media sosial Instagram untuk memenuhi kebutuhan aktualisasi diri mereka, dan di balik quotes tersebut terdapat maksud lain yang berhubungan dengan konsep Johari Windows. Meskipun quotes yang dibuat dalam bentuk quotes dakwah atau inspirasi, hal tersebut juga sekaligus menjadi ajang dalam mencurahkan perasaan, pikiran, dan pengalaman hidup.
\end{abstract}

Kata Kunci: Self disclosure, Johari Window, media sosial, Instagram

\section{ABSTRACT}

This study aims to determine the concept of Johari Window toward Gallery Quote's Member in conducting self disclosure activities through social media Instagram. This research is a qualitative research with case study approach. Technique of data analysis is done through observation on Instagram Gallery Quote's account by analyzing text post in the form of comments given by Instagram's users. Data analysis was done by using Miles \& Huberman model since it related to research problem: self disclosure on Gallery Quote's member. The results of this study show that members of Gallery Quote utilize social media Instagram to meet their self actualization needs, and behind the quotes there is another meaning associated with the Johari Windows concept. Although the quotes are made in the form of 'da'wah or inspiration quotes, they also serve as a venue for devoting feelings, thoughts, and life experiences.

Keywords: Self disclosure, Johari Window, Social Media, Instagram

\section{PENDAHULUAN}

Dalam kehidupan sehari-hari, pengungkapan diri atau self disclosure berlangsung tidak hanya dalam komunikasi dan interaksi langsung antarmanusia, tetapi dapat pula terjadi lewat media perantara, yaitu melalui media sosial. Pengungkapan diri melalui media sosial ini pada umumnya dilakukan dalam bentuk status, foto/video, chatting, komentar, dan lainlain terkait kejadian yang dialami dan perasaan yang sedang dirasakan agar diketahui oleh

Citation : Sagiyanto, Asriyani dan Nina Ardiyanti. (2018). "Self Disclosure melalui Media Sosial Instagram (Studi Kasus pada Anggota Galeri Quote)". Nyimak Journal of Communication, 2(1): 81-94. 
sesama pengguna akun media sosial terkait. Dalam sebuah studi yang dilakukan oleh tim peneliti dari Universitas Wisconsin, Amerika Serikat, yang melibatkan 300 mahasiswa, didapati bahwa sebanyak $70 \%$ responden membagikan perasaannya lewat media sosial, SMS, dan telepon (dalam Arifiani, 2014).

Media sosial juga banyak digunakan untuk mengekspresikan emosi tertentu yang dialami oleh seseorang. Hal ini merupakan salah satu bentuk pengungkapan diri (self disclosure), yakni komunikasi yang disengaja lewat perilaku verbal yang menjelaskan mengenai pengalaman/perasaan seseorang (Bazarova \& Choi, 2014; Mahendra, 2017; Lin, Tov \& Qiu, 2014; Pohan \& Dalimunthe, 2017; Ayun, 2015; Arnus, 2016; Ayub, Maulina \& Alif, 2017; Yu, Jen-Hwa \& Cheng, 2015; Ayudhya, 2017; Dominick, 1999; Schau \& Gilly, 2003).

Salah satu media sosial yang digunakan untuk self disclosure dan semakin berkembang pada saat ini adalah Instagram (Kusyanti \& Safitri, 2016; Williamson [et al.], 2017; Al-Kandari, Melkote \& Sharif, 2016). Hingga April 2017, pengguna Instagram tercatat telah mencapai 700 juta pengguna. Menurut pernyataan Brand

Development Lead Instagram Paul Webster, Indonesia merupakan negara dengan jumlah pengguna Instagram yang terbanyak, di mana sebanyak 89\% penggunanya berusia 18-34 tahun dan mereka mengakses Instagram setidaknya seminggu sekali (Mailanto, 2016).

Dari sekian banyak akun Instagram yang ada, Galeri Quote menjadi salah satu akun yang menginspirasi para pengguna Instagram supaya berkarya melalui quote, memecomic Islam, poster dakwah dan tulisan-tulisan lainnya yang tentunya bermanfaat dan dapat diterima semua kalangan pengguna Instagram. Berdasarkan observasi yang dilakukan oleh peneliti sendiri, akun ini berawal dari grup aplikasi WhatsApp Messenger yang kemudian membuat sebuah akun di Instagram pada 7 Maret 2017 dengan nama akun @galeriquote. Tercatat sebanyak 191.000 pengguna Instagram menjadi followers akun ini (per 15 Agustus 2017, kemungkinan masih akan terus bertambah). Angka belasan ribu ini tentunya cukup menjelaskan bahwa Galeri Quote menarik minat pengguna media sosial Instagram karena akun Galeri Quote tersebut memberikan kata-kata yang ringan untuk dicerna, memotivasi, dan menginspirasi pembacanya (followers).

Hal yang memotivasi Galeri Quote untuk selalu membagikan karya-karya yang bermanfaat dan saling berbagi hal-hal positif. Oleh sebab itu, anggota Galeri Quote merupakan pelaku utamanya, yaitu sebagai komunikator yang harus terampil berkomunikasi, kaya ide serta kreativitas. Menurut Cangara (2016), komunikator akan disalahkan apabila komunikasi yang dilakukan tak mengena kepada sasaran . Komunikator harus mengetahui lebih awal tentang kesiapan dirinya, pesan yang ingin disampaikan, media yang akan digunakan, hambatan yang mungkin ditemui, dan khalayak yang akan menerima pesannya. 
Menurut Cangara (2016), suatu upaya untuk memahami diri sendiri terkait dengan sebuah konsep yang dikenal dengan nama "Johari Window", sebuah kaca jendela yang terdiri dari empat bagian di mana keempat wilayah di dalamnya ialah satu kesatuan (100\%) yang terdapat pada diri setiap orang, yaitu wilayah terbuka, buta, tersembunyi dan tidak dikenal. Karena itu, masing-masing individu di dalam suatu kelompok melakukan kegiatan self disclosure tidak dengan cara yang sama, karena masing-masing individu tersebut mempunyai kadar wilayah yang berbeda satu sama lain, dan hal inilah yang sering kali menimbulkan masalah dalam Galeri Quote. Misalnya masih ada anggota Galeri Quote yang membuat quote yang tidak sesuai dengan aturan Galeri Quote, seperti membuat quote dengan latar belakang wanita baik tidak berhijab atau berhijab syar'i. Sebenarnya, tidak semua hal yang keluar dari pikiran dan perasaan mereka hanya sebatas ungkapan biasa saja, tetapi ada hal lainnya yang melatarbelakangi karya tersebut. Dalam konteks ini, Galeri Quote mengemas dengan kata-kata yang penuh makna dan menginspirasi supaya ajang pencurahan isi pikiran dan perasaan dapat tetap terkendali.

Berdasarkan penjelasan di atas, peneliti tertarik untuk meneliti lebih dalam bagaimana cara mereka mengkomunikasikan identitas sosialnya melalui berbagai kegiatan Galeri Quote yang didukung dengan fitur-fitur yang dimiliki media sosial Instagram. Dikaitkan dengan konsep Johari Window maka penelitian ini bertujuan untuk mengetahui konsep Johari Window anggota Galeri Quote dalam melakukan kegiatan self disclosure melalui media sosial Instagram.

\section{KERANGKA TEORI}

\section{Komunikasi dengan Diri Sendiri (Intrapersonal Communication)}

Menurut Cangara (2016), komunikasi dengan diri sendiri merupakan suatu proses komunikasi yang terjadi di dalam diri individu atau proses berkomunikasi dengan diri sendiri. Sementara menurut Mulyana (2013), komunikasi intrapribadi adalah komunikasi dengan diri sendiri, seperti berpikir. Komunikasi ini adalah landasan komunikasi antarpribadi dan komunikasi pada konteks-konteks lainnya meskipun dalam disiplin komunikasi tak dibahas secara rinci dan tuntas. Pengungkapan diri yang dilakukan di dunia maya merupakan bentuk komunikasi intrapersonal yang berhubungan dengan seberapa banyak individu berbicara tentang dirinya sendiri, seperti minat pribadi, aktivitas pribadi, sikap pribadi, dan sejenisnya. 


\section{Pengertian Self Disclosure}

Menurut Sears (2001), pengungkapan diri atau keterbukaan diri adalah kegiatan membagikan perasaan dan informasi yang akrab dengan orang lain. Morton (dalam Sears, 2001) menyatakan bahwa pengungkapan diri dapat bersifat deskriptif atau evaluatif. Dalam pengungkapan diri deskriptif, kita melukiskan fakta-fakta terkait diri kita yang mungkin belum diketahui oleh pendengar-pekerjaan, tempat tinggal kita, atau partai yang kita dukung di pemilihan umum, dan lain sebagainya. Dalam pengungkapan diri evaluatif, kita mengemukakan pendapat atau perasaan pribadi jika kita menyukai orang-orang tertentu, bahwa kita merasa cemas karena terlalu gemuk, bahwa kita tidak suka bangun pagi.

Menurut Devito (2011), pengungkapan diri adalah informasi mengenai diri sendiri, tentang pikiran, perasaan, dan perilaku seseorang, atau tentang orang lain yang sangat dekat yang sangat dipikirkan. Jadi, pengungkapan diri dapat diartikan sebagai tindakan Anda sendiri atau tindakan, misalnya, orang tua atau anak Anda, karena mereka mempunyai hubungan langsung dengan Anda.

Sementara menurut Derlega, dkk (dalam Devito, 2011), dinyatakan bahwa pengungkapan diri sebagai setiap informasi tentang diri sendiri. Menurut Derlega, sebaiknya kita lebih memusatkan kepada informasi yang biasanya disembunyikan daripada daripada segala jenis informasi yang belum diungkapkan. Pengungkapan diri adalah informasi yang biasanya tidak akan Anda ungkapkan dan Anda secara aktif berusaha tetap menjaga kerahasiaannya.

\section{Teori Self Disclosure}

Menurut Cangara (2016), kegiatan mengenal diri adalah hal yang penting jika kita menempatkan diri di tengah-tengah masyarakat. Dengan mengenal diri, kita dapat mengetahui kelebihan dan kelemahan yang ada dalam diri kita. Untuk memahami diri sendiri, Joseph Luft dan Harrington Ingham memperkenalkan sebuah konsep yang dikenal sebagai Johari Window, sebuah kaca jendela yang terdiri dari empat bagian antara lain wilayah terbuka (open area), wilayah buta (blind area), wilayah tersembunyi (hidden area), wilayah tak dikenal (uknown area).

1. Wilayah Terbuka

Di wilayah terbuka kita mengenal diri kita dalam hal kepribadian, kelebihan, dan kekurangan. Menurut konsep ini, kepribadian, kelebihan, dan kekurangan yang kita miliki selain diketahui oleh diri sendiri juga diketahui oleh orang lain. Jadi, jika kita ingin sukses berkomunikasi, kita harus mampu mempertemukan keinginan kita dan keinginan orang lain. Jika wilayah terbuka semakin melebar dalam arti kita bisa memahami orang lain dan orang lain dapat memahami diri kita, akan terjadi komunikasi yang mengena. 
Sebaliknya, jika wilayah terbuka ini makin mengecil berarti komunikasi kita cenderung semakin tertutup.

2. Wilayah Buta

Di wilayah buta orang tidak mengetahui kekurangan yang dimilikinya, namun sebaliknya kekurangan itu justru diketahui oleh orang lain. Di berbagai kasus, banyak orang tidak mengetahui kelemahannya, bahkan berusaha menyangkal jika hal itu ada dalam dirinya. Oleh sebab itu, jika wilayah buta makin melebar dan mendesak wilayah ini, maka akan terjadi kesulitan komunikasi. Menurut Joseph Luft dan Harrington, wilayah buta ini ada pada setiap manusia dan sulit dihapus sama sekali, kecuali mengurangi. Salah satu caranya adalah bercermin pada nilai, norma, dan hukum yang diikuti oleh orang lain.

3. Wilayah Tersembunyi

Pada wilayah tersembunyi, kemampuan yang kita miliki tersembunyi sehingga tak diketahui oleh orang lain. Ada dua konsep yang erat hubungannya dengan wilayah tersembunyi, yaitu overdisclose dan underdisclose. Overdisclose ialah sikap terlalu banyak mengungkapkan sesuatu sehingga hal-hal yang harusnya disembunyikan juga diutarakan, seperti konflik rumah tangga, utang, dan lain-lain. Sedangkan underdisclose adalah sikap terlalu menyembunyikan sesuatu yang seharusnya dikemukakan. Pada pengobatan gangguan kejiwaan misalnya, sikap underdisclose bisa menyulitkan sang psikiater, sebab pasien sangat sulit menyampaikan informasi yang diperlukan untuk pengobatan dirinya. Sikap lain dari underdisclose ini ialah terlalu banyak tahu tentang orang lain, namun tidak mau bicara tentang dirinya.

4. Wilayah Tak Dikenal

Wilayah tak dikenal merupakan wilayah yang paling kritis dalam komunikasi. Selain kita sendiri yang tidak mengenal diri, orang lain tidak mengetahui siapa kita. Dalam kehidupan sehari-hari, sering terjadi kesalahan persepsi dan atau kesalahan perlakuan terhadap orang lain karena tidak saling mengenal baik itu menyangkut kelebihan, kekurangan maupun statusnya (siapa dia).

Menurut Joseph Luft dan Harrington Ingham, empat wilayah pada konsep Johari Window merupakan satu kesatuan (100\%) yang terdapat dalam diri setiap orang. Hanya saja, kadar wilayahnya itu sangat berbeda antara satu orang dengan yang lain. Orang yang ingin sukses bermasyarakat, ia harus memperbesar wilayah terbuka. Dengan memperbesar wilayah terbuka, tiga wilayah lain akan mengecil. 


\section{Definisi Media Sosial}

Menurut Nasrullah (2017), munculnya budaya berbagi dan pengungkapan diri (self disclosure) di dunia maya salah satunya merupakan dampak dari media sosial. Budaya ini muncul karena media sosial yang memungkinkan siapa pun bisa mengunggah apa pun. Pengungkapan itu menjadi suatu budaya yang pada akhirnya mengaburkan batas-batas antara ruang pribadi dan ruang publik. Sebuah status di Facebook misalnya, bisa saja bercerita mengenai kondisi yang dialami si pemilik akun. Tetapi layaknya dalam proses komunikasi dua arah, kepada siapa status itu disampaikan pun tidak dapat dijelaskan. Sebab, siapa pun dapat membaca status tersebut dan siapa pun juga dapat mengomentarinya meskipun tak dalam jaringan pertemanan si pemilik akun.

Sedangkan menurut Dijk (dalam Nasrullah, 2017), media sosial diartikan platform media yang memfokuskan pada eksistensi pengguna yang memfasilitasi mereka dalam beraktivitas maupun berkolaborasi. Karena itu, media sosial dapat dilihat sebagai fasilitator online yang menguatkan hubungan antarpengguna serta sekaligus menjadi suatu ikatan sosial (Spiekermann [et al.], 2012; Stutzman, 2006; Ridings, Gefen \& Arinze, 2002; Feng, Lazar \& Preece, 2007).

\section{Karakteristik Media Sosial}

Menurut Tim Pusat Humas Kementerian Perdagangan RI (2014: 27), media sosial memiliki enam (6) ciri sebagaimana berikut ini.

1. Konten yang disampaikan dibagikan kepada banyak orang dan tidak terbatas pada satu orang tertentu.

2. Isi pesan muncul tanpa melalui gatekeeper dan tidak ada gerbang penghambat.

3. Isi disampaikan secara online dan langsung.

4. Konten dapat diterima secara online dalam waktu lebih cepat dan bisa tertunda penerimaannya tergantung pada waktu interaksi yang ditentukan sendiri oleh pengguna.

5. Menjadikan para penggunanya sebagai kreator dan aktor yang memungkinkan dirinya untuk beraktualisasi diri.

6. Dalam konten media sosial terdapat aspek-aspek fungsional, seperti identitas, percakapan (interaksi), berbagi (sharing), kehadiran (eksis), hubungan (relasi), reputasi (status) dan kelompok (group).

Dalam buku Panduan Optimalisasi Media Sosial (2014), terdapat berbagai kelebihan yang dimiliki media sosial dibandingkan dengan media konvensional. 
1. Cepat, ringkas, padat dan sederhana. Apabila kita lihat, setiap produksi media konvensional membutuhkan suatu keterampilan khusus, standar yang baku dan kemampuan marketing yang unggul. Sebaliknya media sosial sangatlah mudah digunakan (user friendly). Bahkan, para penggunanya tanpa basis pengetahuan Teknologi Informasi (TI) pun dapat menggunakannya; yang diperlukan hanya komputer, tablet, smartphone, ditambah koneksi internet.

2. Menciptakan hubungan lebih intens. Media konvensional hanya melakukan komunikasi satu arah. Untuk mengatasi keterbatasan itu, media konvensional mencoba membangun hubungan dengan model interaksi atau koneksi secara live melalui telepon, sms. Sebaliknya, media sosial memberikan kesempatan yang luas kepada user untuk berinteraksi dengan mitra, pelanggan, dan relasi, serta membangun hubungan timbal balik secara langsung dengan mereka.

3. Jangkauan luas dan global. Media-media konvensional memiliki daya jangkau secara global, tetapi untuk menopang itu perlu biaya besar dan membutuhkan waktu lebih lama. Melalui media sosial, siapa pun bisa mengkomunikasikan informasi secara cepat tanpa hambatan geografis. Pengguna media sosial juga diberi peluang yang besar untuk mendesain konten sesuai dengan target dan keinginan ke lebih banyak pengguna.

4. Kendali dan terukur. Dengan sistem tracking yang tersedia pada media sosial, pengguna bisa mengendalikan/mengukur efektivitas informasi yang diberikan melalui respons balik serta reaksi yang muncul. Sedangkan pada media-media konvensional, masih membutuhkan waktu yang lama.

\section{Jenis-Jenis Media Sosial}

Media sosial ialah kelompok aplikasi berbasis media internet yang memungkinkan penciptaan serta pertukaran user-generated content. Kaplan dan Haenlein (2010) membuat klasifikasi untuk berbagai jenis media sosial yang ada berdasarkan ciri-ciri penggunaannya. Menurut mereka, pada dasarnya media sosial dapat dibagi menjadi enam jenis.

1. Proyek kolaborasi website, di mana user-nya diizinkan untuk dapat mengubah, menambah, atau membuang konten-konten yang termuat di website tersebut, seperti Wikipedia.

2. Blog dan microblog, di mana user mendapat kebebasan mengungkapkan suatu hal di blog, seperti perasaan, pengalaman, pernyataan, atau kritikan terhadap suatu hal, seperti Twitter.

3. Konten atau isi, di mana user di website ini saling membagikan konten-konten multimedia, seperti e-book, video, foto, gambar, dan lain-lain seperti Youtube. 
4. Situs jejaring sosial, di mana user memperoleh izin supaya terkoneksi dengan cara membuat informasi yang bersifat pribadi, kelompok atau sosial sehingga dapat terhubung atau diakses oleh orang lain, seperti Facebook.

5. Virtual game world, di mana pengguna melalui aplikasi 3D bisa muncul dalam wujud avatar-avatar sesuai keinginan dan kemudian berinteraksi dengan orang lain yang mengambil wujud avatar juga layaknya di dunia nyata, seperti online game.

6. Virtual social world, aplikasi berwujud dunia virtual yang memberi kesempatan penggunanya berada dan hidup di dunia virtual guna berinteraksi dengan yang lain. Virtual social world ini tidak jauh beda dengan virtual game world, tetapi lebih bebas terkait dengan berbagai aspek kehidupan, seperti Second Life.

\section{Instagram}

Welcome to Instagram, ialah kalimat pembuka yang diucapkan Kevin Systrom dan Mike Krieger di blog resminya pada 6 Oktober 2010, menandai lahirnya aplikasi photo sharing revolusioner Instagram. Melalui startup yang didirikannya (Burbn), dua orang anak muda itu berkerja keras untuk mewujudkan layanan jejaring sosial berbasis fotografi sesuai impiannya (Atmoko, 2012).

Sebagai aplikasi berbagi foto, para pengguna Instagram dapat mengambil foto, menerapkan filter digital, dan membagikannya ke berbagai layanan jejaring sosial, termasuk Instagram milik sendiri. Salah satu fitur yang unik di Instagram adalah memotong foto menjadi bentuk persegi hingga terlihat seperti hasil kamera Kodak Instamatic dan Polaroid. Hal ini berbeda dengan rasio aspek 4:3 yang pada umumnya digunakan oleh kamera pada peralatan bergerak.

Instagram dapat digunakan di iPhone, iPad atau iPod Touch versi apapun dengan sistem operasi iOS 3.1.2 atau yang terbaru dan telepon kamera Android apapun dengan sistem operasi 2.2 (Froyo) atau yang terbaru. Aplikasi ini tersebar melalui Apple App Store dan Google Play.

Nama Instagram sendiri terdiri dari kata insta dan gram. Kata insta berasal dari kata instan, seperti kamera polaroid yang pada masanya lebih dikenal dengan sebutan "foto instan". Instagram juga dapat menampilkan foto-foto secara instan, seperti polaroid pada tampilannya. Sedangkan kata gram berasal dari kata telegram yang berfungsi mengirim informasi kepada orang lain dengan cepat. Sebagaimana halnya telegram, Instagram bisa mengunggah foto sekaligus mengirimnya dengan cepat (instan-telegram). 
Ketika pertama kali dirilis pada tanggal 6 Oktober 2010, sebanyak 25 ribu pengguna berhasil terjaring untuk mendaftar di hari pertama. Aplikasi ini sangat disukai karena kemudahan dan kecepatannya dalam berbagi foto, ditambah lagi beberapa filter bergaya retro yang menarik. Penggunannya bisa memanfaatkan 17 filter foto untuk mengubah nuansa warna dan memberi kesan foto yang berbeda. Semenjak dirilis, Instagram telah memberikan cara baru berkomunikasi di jejaring sosial melalui foto .

Komunikasi antarsesama pengguna Instagram sendiri dapat terjalin dengan memberikan tanda suka atau mengomentari foto yang diunggah pengguna lainnya. Pengikut juga menjadi salah satu unsur yang penting, di mana jumlah tanda suka dari para pengikut sangat memengaruhi apakah foto tersebut dapat menjadi foto yang populer atau tidak.

\section{METODE PENELITIAN}

Penelitian ini adalah penelitian kualitatif dengan pendekatan studi kasus. Dengan menggunakan pendekatan studi kasus, peneliti berharap mampu mengungkap self disclosure pada anggota Galeri Quote melalui media sosial Instagram. Sumber data primer penelitian ini berasal dari observasi dan wawancara mendalam, sementara data primer diperoleh melalui studi pustaka dan dokumentasi. Teknik analisis data dilakukan melalui observasi pada akun Instagram Galeri Quote, yang dengan cara menganalisis postingan teks berupa komentar-komentar yang diberikan pengguna Instagram. Analisis juga dilakukan terhadap postingan berbagai quote dengan foto, gambar, geotagging dan lain sebagainya yang muncul pada aktivitas timeline akun Instagram responden. Peneliti juga melakukan analisis data berkaitan dengan masa aktif penggunaan Instagram pada responden penelitian yang dipilih dengan masa pengguna 1 sampai 1 tahun lebih. Analisis data dilakukan dengan menggunakan model Miles \& Huberman karena berkaitan dengan masalah penelitian, yaitu self disclosure (pengungkapan diri) individu pada Galeri Quote.

\section{HASIL DAN PEMBAHASAN}

Konsep Johari Window merupakan konsep yang terdapat dalam diri setiap orang. Menurut Joseph Luft dan Harrington Ingham, ada empat wilayah di dalam konsep ini, terdiri dari wilayah terbuka (open area), wilayah buta (blind area), wilayah tersembunyi (hidden area) dan wilayah tak dikenal (uknown area). Empat wilayah tersebut adalah satu kesatuan (100\%) di dalam diri setiap orang. Hanya saja, kadar wilayahnya berbeda-beda antara satu orang dengan orang yang lain (Newstrom \& Rubenfeld, 1983). Begitu pula dengan anggota Galeri Quote yang setiap individu memiliki kadar pengungkapan diri yang berbeda antara satu dengan yang lainnya, meskipun mempunyai maksud yang sama dalam membuat quotes di 
Galeri Quote. Seperti yang diungkapkan oleh salah satu informan pendukung (Dea), yang dalam pernyataan sebelumnya mengaku bahwa ia adalah sosok introvert yang amat sulit bersosialisasi dengan orang lain sehingga untuk bercerita mengenai perasaan dan pikiran pun juga sulit, dan ia hanya bisa menyalurkan melalui karya-karya tulisan seperti quotes berikut ini.
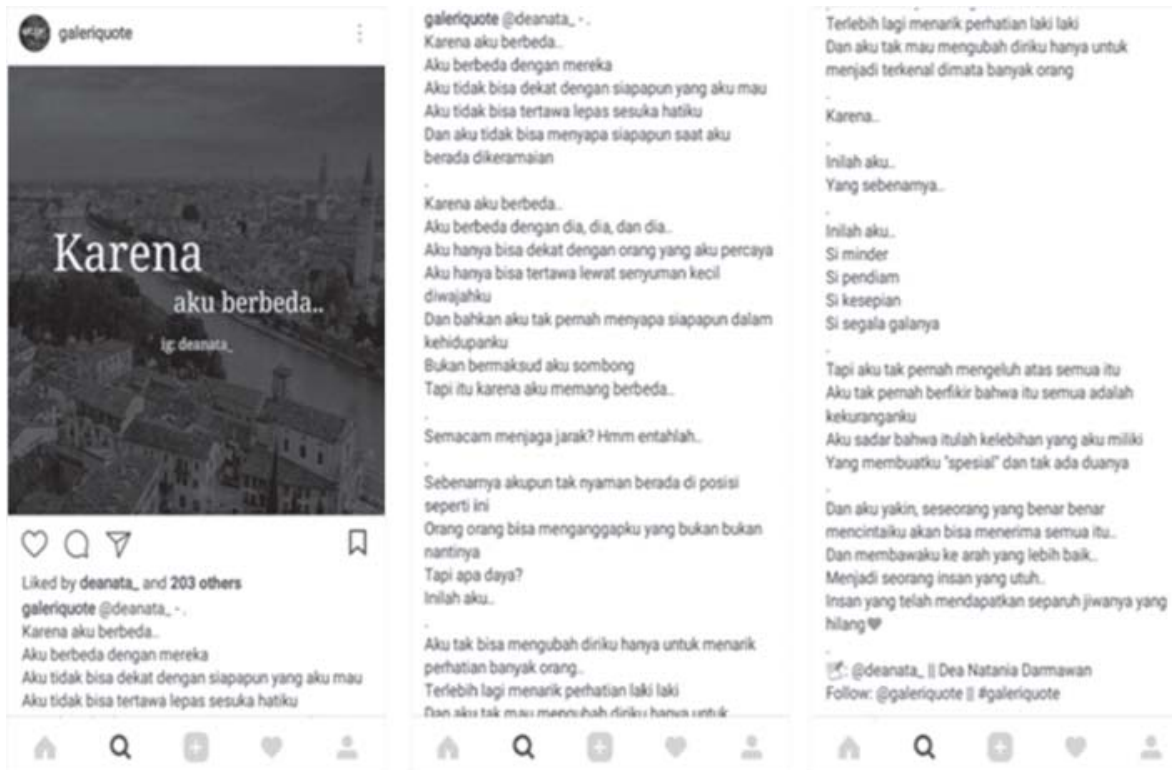

Gambar 1. Caption Quote pada Akun Instagram Gallery Quote

Quotes yang dibuat tersebut tidak semata-mata hanya membuat kemudian dipost, namun berasal dari pikiran, perasaan, dan pengalaman baik itu dialami diri sendiri maupun orang lain yang sebelumnya tak dapat diungkapkan di dunia nyata namun dapat diungkapkan melalui media sosial Instagram. Dalam hal ini, Galeri Quote merupakan wadah bagi anggotanya untuk melakukan self disclosure namun dikemas secara kreatif serta sopan secara bahasa yang tentunya juga bisa memberi manfaat bagi para pengguna Instagram yang lainnya. Karena itu, dapat dikatakan bahwa ketika menulis quote, anggota Galeri Quote sedang memperbesar wilayah terbuka dibandingkan dengan ketiga wilayah lainnya, karena mereka ternyata bisa mengungkapkan perasaan, pikiran, dan pengalaman melalui Instagram.

Konsep Johari Window Anggota Galeri Quote melalui Instagram

Dalam bersosialisasi terjadi proses interaksi di dalamnya. Interaksi tersebut akan ada informasi tentang diri yang dibagikan satu sama lain, berkaitan dengan sebuah identitas diri, perasaan dan keadaan yang dialami. Seperti yang dilakukan anggota Galeri Quote dalam 
membagikan informasi dan identitas diri yang dideskripsikan melalui Galeri Quote yang dapat langsung terhubung dengan akun pribadi setiap anggota Galeri Quote, karena setiap quotes yang dishare dalam akun Galeri Quote akan ada nama penulis quotes tersebut dan setiap tulisan quotes yang dibuat dari setiap anggota memiliki karakter masing-masing. Secara evaluatif, anggota Galeri Quote melakukan pengungkapan diri dengan cara menceritakan perasaan, pikiran, dan pengalaman yang mereka alami melalui quotes yang dishare pada akun Galeri Quote

Dalam pengungkapan diri deskriptif, kita melukiskan berbagai fakta terkait diri kita yang mungkin belum diketahui pendengar-pekerjaan, tempat tinggal kita, partai politik yang kita dukung, dan lain-lain. Dalam pengungkapan diri evaluatif, kita mengemukakan pendapat atau perasaan pribadi bahwa kita menyukai orang-orang tertentu, bahwa kita merasa cemas karena terlalu gemuk, bahwa kita tidak suka bangun pagi, dan lain sebagainya.

Setiap orang memiliki alasan dalam memilih media yang digunakan untuk melakukan pengungkapan diri, seperti halnya anggota Galeri Quote yang memilih Instagram dalam membagikan karya quotes, hal ini berarti media sosial Instagram dapat memenuhi kebutuhan dari setiap anggota Galeri Quote.

Dengan fitur-fitur yang dimiliki Instagram, seperti filter-filter yang menurut mereka sesuai untuk pembuatan quotes, Instagram juga memberikan kemudahan dan kenyamanan pada saat digunakan untuk menjalin pertemanan antara anggota Galeri Quote dan sesama pengguna Instagram lainnya.

Ketika anggota Galeri Quote memilih media sosial Instagram yang kiranya tepat digunakan untuk memenuhi kebutuhan mereka, di balik quotes itu terdapat maksud lain yang berhubungan dengan konsep Johari Windows. Meskipun quotes yang dibuat dalam bentuk quotes dakwah, inspirasi, namun hal tersebut justru juga dijadikan ajang mencurahkan perasaan, pikiran, dan pengalaman hidup.

Namun, pengungkapan diri yang dilakukan kelompok atau grup, tak sama atau tidak sebebas jika dibandingkan dengan akun pribadi lantaran ada ketentuan yang harus diikuti oleh setiap anggota. Selain itu, berbagai perbedaan karakter di pada kelompok akan menghasilkan self disclosure yang berbeda-beda pula karena tidak setiap saat perasaan seeorang selalu positif. Akan tetapi, hal tersebut justru dapat dijadikan sebagai pengendalian diri dan pengingat diri (self reminder) dalam membagikan dan menyampaikan informasi . Selain itu, sesama anggota juga dapat belajar dan membagi pengalaman satu sama lain mengenai kehidupan agar konten yang dibuat dan dibagikan dapat lebih baik, entah sewaktu membagikan konten di ataupun ketika membagikan konten di akun masing-masing anggota 
Galeri Quote. Menurut penjelasan yang sudah dijabarkan dapat disimpulkan bahwa Galeri Quote menjadi wadah para creator Instagram untuk mencurahkan perasaan, pikiran serta membagikan pengalaman yang dituangkan melalui quotes. Dalam hal ini, anggota Galeri Quote terbuka dalam menulis quotes yang dikemas dengan kata-kata yang berbeda dalam konteks positif dan dapat menginspirasi para pengguna Instagram lainnya.

\section{KESIMPULAN}

Berdasarkan penjelasan yang telah dikemukakan di atas, peneliti menyimpulkan bahwa anggota Galeri Quote masuk ke wilayah terbuka (open area) yang ditandai dengan apa yang mereka tulis dalam bentuk quote yang merupakan hasil pikiran, perasaan yang sedang dirasakan, dan pengalaman dalam kehidupan. Pada saat itu, mereka memperbesar wilayah terbuka dibandingkan dengan wilayah lainnya yang otomatis akan mengecil dengan sendirinya. Jadi, mereka lebih nyaman dan terbuka pada saat menulis quotes melalui media sosial Instagram.

\section{REFERENSI}

Al-Kandari, Ali, Srinivas R. Melkote and Ahmad Sharif. (2016). "Needs and Motives Of Instagram Users that Predict Self-Disclosure Use: A Case Study of Young Adults in Kuwait". Journal of Creative Communications, 11(2): 85-101.

Arifiani, Septina. (1 Agustus 2014). Duh, Curhat di Media Sosial Justru Bisa Bikin Anda Merasa Lebih Buruk. Diakses dari: http://www.jatengpos.com/2014/08/hasil-penelitian-duhcurhat-di-media-sosial-justru-bisa-bikin-anda-merasa-lebih-buruk-523202

Arnus, Sri Hadijah. (2016). "Self Disclosure di Media Sosial pada Mahasiswa IAIN Kendari (Suatu Kajian Psikologi Komunikasi Pada Pengguna Media Sosial)". Al-Izzah, 11(2): 1-18. Atmoko, Dwi Bambang. 2012. Instagram Handbook: Tips Fotografi Ponsel. Jakarta: Media Kita.

Ayub, Kanda, Novaria Maulina dan Muhammad Alif. (2017). "Self Disclosure Chef Agus Sasirangan di Media Sosial Instagram". Meta Communication: Journal of Communication Studies, 1(2): 1-13.

Ayudhya, Fentira. (2017). “Instagram dan Presentasi Diri Mahasiswa (Studi Korelasional Penggunaan Instagram Terhadap Presentasi Diri Mahasiswa Fakultas IImu Sosial dan IImu Politik Departemen IImu Komunikasi Universitas Sumatera Utara)". Flow, 3(5): 1-10. Ayun, Primada Qurrota. (2015). "Fenomena Remaja Menggunakan Media Sosial dalam Membentuk Identitas". Channel (Jurnal Komunikasi), 3(2): 1-6. 
Bazarova, Natalya N. and Yoon Hyung Choi. (2014). "Self-Disclosure in Social Media: Extending the Functional Approach to Disclosure Motivations and Characteristics on Social Network Sites". Journal of Communication, 64(4): 635-657.

Cangara, Hafied. (2016). Pengantar Ilmu Komunikasi. Jakarta: Rajawali Pers.

Devito, Joseph. (2011). Komunikasi Antar Manusia. Tangerang Selatan: Karisma Publishing Group.

Dominick, Joseph R. (1999). "Who Do You Think You Are? Personal Home Pages and SelfPresentation on the World Wide Web". Journalism \& Mass Communication Quarterly, 76(4): 646-658.

Feng, Jinjuan, Jonathan Lazar and Jenny Preece. (2007). “Empathy and Online Interpersonal

Trust: A Fragile Relationship". Behaviour \& Information Technology, 23(2): 97-106.

Jongtae Yu, Paul Jen-Hwa \& Tsang-Hsiang Cheng. (2015). "Role of Affect in Self-Disclosure on Social Network Websites: A Test of Two Competing Models". Journal of Management Information Systems, 32(2): 239-277.

Kaplan, Andreas and Michael Haenlein. (2010). "Users of the World, Unite! The Chalanges and Opportunities of Social Media", Business Horizons, 53(1): 59-68.

Kusyanti, Ari dan One Safitri. (2016). "How Do I Look: Self-Disclosure of Instagram Users in Indonesia". Journal of Education and Social Sciences, 5(2): 242-247.

Lin, Han, William Tov and Lin Qiu. (2014). "Emotional Disclosure on Social Networking Sites: The Role of Network Structure and Psychological Needs". Computers in Human Behavior, 41, 342-350.

Mahendra, Bimo. (2017). "Eksistensi Sosial Remaja dalam Instagram (Sebuah Perspektif Komunikasi)". Jurnal Visi Komunikasi, 16(1): 151-160.

Mailanto, Arsan. (14 Januari 2016). Pengguna Instagram di Indonesia Terbanyak, Mencapai 89\%. Diakses dari: https://techno.okezone.com/read/2016/01/14/207/1288332/penggunainstagram-di-indonesia-terbanyak-mencapai-89

Nasrullah, Rulli. (2017). Media Sosial: Perspektif Komunikasi, Budaya, dan Sosioteknologi. Bandung: Simbiosa Rekatama Media.

Newstrom, John W. and Stephen A. Rubenfeld. (1983). "The Johari Window: A Reconceptualization". Developments in Business Simulation \& Experiential Exercises, 10, 117-120.

Pohan, Fionna Almira \& Hairul Anwar Dalimunthe. (2017). "Hubungan Inmate Friendship dengan Self-Disclosure pada Mahasiswa Psikologi Pengguna Media Sosial". Jurnal Diversita, 3(2): 15-24. 
Ridings, Catherine M., David Gefen and Bay Arinze. (2002). "Some Antecedents and Effects of Trust in Virtual Communities". Journal of Strategic Information Systems, 11(3-4): 271295.

Salamoon, Daniel Kurniawan. (2013). Instagram, Ketika Foto Menjadi Mediator Komunikasi Lintas Budaya Di Dunia Maya. Makalah Konferensi. Diakses dari: http:// repository.petra.ac.id/16642/

Schau, Hope Jensen and Mary C. Gilly. (2003). "We Are What We Post? Self Presentation in Personal Web Space". Journal of Consumer Research, 30(3): 385-404.

Sears, David O. (2001). Psikologi Sosial. Jakarta: Erlangga.

Spiekermann, Sarah [et al.]. (2012). "Online Social Networks: Why We Disclose”. Journal of Information Technology, 25(2): 109-125.

Stutzman, F. (2006) "An Evaluation of Identity-Sharing Behavior in Social Network Communities". International Digital and Media Arts Journal, 3(1): 10-18.

Williamson, Patricia [et al.]. (2017). "Me, My 'Selfie' and I: A Survey of Self-disclosure Motivations on Social Media". IAFOR Journal of Cultural Studies, 2(2): 71-85. 